ANDRZEJ PIERZCHAŁA

Grodzisk Mazowiecki

\title{
THE EAST INDIA COMPANY AND THE PIRATES OF THE PERSIAN GULF FROM THE FIRST PUNITIVE EXPEDITION TO THE SIGNING OF THE GENERAL MARITIME TREATY
}

Great Britain/the UK has been interested in the Persian Gulf region since the $17^{\text {th }}$ century, when the influence of the East India Company ${ }^{1}$, growing in power and striving to strengthen its position, started to reach out into these waters and ports. Significant fragmentation of the territories surrounding the shores of the Persian Gulf as well as numerous conflicts - not only local ones but also those stemming from the struggle for influence between the Ottomans, Persia or Oman - made practically impossible the creation of a strong state, one that was able to stop the growth of piracy and guarantee undisturbed trade. Besides, for these waters, so rich in booty, it was not anything new. The first recorded account of the piracy in this region (it is worth noting the prevalence of the scourge of piracy gave rise to the territories of the present-day United Arab Emirates been nicknamed The Pirate Coast ${ }^{2}$ ), are found in 10th century writings of Ibn Hawqal ${ }^{3}$. They appear repeatedly in documents, letters or chronicles through the following ages. Although Basra and Bahrain ${ }^{4}$ were considered as strong pirate bases, in the $18^{\text {th }}$ century the biggest problem for the British were Musandam pirates ${ }^{5}$, against whom the Company tried to take the most active steps ${ }^{6}$. While it is debatable among the historians if the matter of piracy was not overstated by the authorities of the Company in order to find a pretext for an intervention in that region and broadening their influence, it remains indisputable that regardless of the aspirations of the British and their intentions towards the emirates of the Persian Gulf, piracy played the significant role in this region as an obstacle for trade. In the last years of the $18^{\text {th }}$ century this "business" had become powerful to such degree that in 1809 the British government - hungry for any profits it was

\footnotetext{
1 The Honourable East India Company is an object of many large publications, e.g.Trading Places: The East India Company and Asia, 1600-1834 by Anthony Farrington or very popular: The Honourable Company: A History of the English East India Company by John Keay.

2 See Charles Belgrave, The Pirate Coast, London 1966.

3 Muhammad Abū'l-Qāsim Ibn Ḥawqal - a traveller, geographer and writer born on the territory of present-day Iraq. His most important work is the book Surat al-Ard (The Book on the Shape of the Earth).

4 R. Hodges, Mohammed, Charlemagne \& the origins of Europe: Archaeology and the Pirenne Thesis, New York, 1983, 149.

5 It was already the members of the tribe of Al Qasimi.

6 British National Archives, ADM 344/1229
} 
able to gather during the Continental Blockade and long-term conflict in Europe - allowed the anti-piracy cooperation of Royal Navy and the Company's ships?

Ships under the rule of the Al Qasimi tribe were responsible for an appreciable part of pirate operations in the region of the Strait of Hormuz. The scant presence of either the British or Company's fleet during the Napoleonic Wars, the scale of the attacks by these ships must have been enormous, considering that a warship with twenty-four guns ${ }^{8}$ barely managed to escape. Naturally, peace in this region was not considered desirable by France, making regular diplomatic efforts to provoke both the pirates and the local countries of Muscat and Persia ${ }^{9}$. Small sailing vessels of dhow or bagala ${ }^{10}$ type were widely available, easy to conceal and commonly used in attacks on merchant ships. According to Richard Woodman, in 1809 the Al Qasimi alone had at their disposal a fleet on the Red Sea and in the Persian Gulf, consisting of sixty large and eight hundreds small units, carrying on their decks nineteen thousand mariners and soldiers ${ }^{11}$. At the same time, British forces - or, to be precise, the Company's forces - in the region comprised at that time of merely two ships: the aforementioned Mornington with 22 guns, accompanied by Teignmouth with 16 guns ${ }^{12}$.

At the end of the monsoon season the forces had been concentrated in Bombay in order to carry out the pacification of pirate bases. They consisted of eight vessels of the Company, a bomb ketch and two Royal Navy frigates. There was a battalion of the 65th Foot soldiers ${ }^{13}$ and another of the 47th Foot ${ }^{14}$, along with soldiers, gunners and engineers of the Company ${ }^{15}$. Once ready the force took off to the Persian Gulf. The journey, delayed by the necessity of providing the escort to the Company's convoys, was quite long. When the British forces reached Muscat, local representatives informed them that the tribes, warned in advanced, had gathered appreciable forces to resist them. For this reason the leader of the expedition, commodore Wainwright, decided on a round of minor attacks on pirate bases and not a general confrontation.

A letter from commodore Wainwright, commander of the squadron, to rear admiral Drury, Commander-in-chief of the East India Station, dated on the $14^{\text {th }}$ of November 1809 , Ras al-Khaimah.

"Sir,-I have the honour to acquaint your excellency, that by the exertion of the troops and the squadron, under the respective commands of Lieutenant-Colonel Smith and myself, Ras al Khyma, the principle town of the pirates who have so long infested the

\footnotetext{
Ibid.

8 R. Woodman, The Victory of Seapower, 1806 - 1814, London 2003, 89.

9 Not only carrying out military operations with the use of its cruisers, but also intensive diplomatic activity such as the incident in Muscat, when imam Saiyid Sa'id (who later will keep appearing in this article) removed a mooring British ship from the port, straight under the French guns. British Library, Asian and African Studies, $\mathrm{IOR} / \mathrm{F} / 4 / 257 / 5650$

10 Dhow are traditional Arabian sailing vessels, able to carry from twelve to forty sailors. Bagalais their sea-going equivalent, a bit bigger and more resistant. A. A.J. Thabit, The Political Economy of Trade in Eighteenth-Century Basra, Nowy York 2000.

11 R. Woodman, The Victory of Seapower, 1806 - 1814, London 2003, 89.

12 I. Lee, Commodore Sir John Hayes: His voyage and life (1767-1831) with some account of Admiral d'Entrecasteaux's voyage of 1792-3, London 2013, 218-220.

13 R. Woodman, The Victory of Seapower, 1806 - 1814, London 2003, 90.

14 Ibid.

15 Ibid.
} 
Persian Gulf, has been completely destroyed, together with all the vessels in the port, amounting to upwards of fifty (about thirty of them very large dows), and of every species of naval stores.

The ships arrived off the place in the afternoon of the 11th instant, but, in consequence of the shallowness of the water, were not able to approach the town within four miles, with the exception of the small cruisers and two of the transports: these anchored from it as near as two miles. On the same evening, the Minerva, an English ship, prize to the pirates, was burned within twice her length of the shore.

On the following day, the town was cannonaded for three hours by the small cruisers and gun-boats with considerable effect; and a little before a daybreak on the 13th instant, a feint was made on the northern end of the place with two gun-boats, under the command of Lieutenant Leslie of La Chiffonne, and a detachment of native troops; and the main attack was commenced on the southern about half an hour afterwards, consistently with an arrangement made by the lieutenant-colonel. The troops were soon landed, and, gallantly executing the admirable plan of their commander, had possession of Ras al Khyma by ten o'clock, driving the enemy to the opposite shore: the gun-boats kept up a fire of grape-shot on the seaside as the soldier advanced. Before four o'clock, all the enemy's vessels were in flames, together with the naval storehouses in the town. ${ }^{16}$ ",

Fifty enemy vessels were destroyed, including thirty large ones ${ }^{17}$. Al Qasimi suffered significant casualties, yet it was not enough to completely stop their activity. A few days' stay by the British squadron in one place allowed news to spread about the expedition force, thus limiting its effectiveness. On the $17^{\text {th }}$ November the expedition force attacked the city of Linga, destroying twenty dhow (including nine large ones) ${ }^{18}$, but all ports visited afterwards were already empty. It was then that the British forces headed toward the main base of the Al Qasimi, the fortress on a small Persian island of Qeshm. Having hired local pilots and blocked means of escape, Commodore Wainwright arrived to the port and after some fruitless negotiations launched an assault upon the enemy's for $\mathrm{t}^{19}$. Hard fights forced the pirates to resume the negotiations that resulted in their capitulation in exchange for a guarantee of their safety. Shortly afterwards, the British forces returned to Bombay.

Although, with the British squadron gone, the pirates started to return to their old fisheries, regain their strength and recreate their fleet. Two cruisers of the Company ${ }^{20}$, Benares and Prince of Wales, were unable to patrol such a vast area alone. This process became more efficient when the forces of the Royal Navy and HEIC were directed to Java ${ }^{21}$. The

\footnotetext{
16 J. Marshall, Royal naval biography, Londyn 1829, vol III, str 87.

17 W. James, The Naval History of Great Britain, London 1827, vol. 5, 67

18 J. Marshall, Royal naval biography, London 1829, vol III, 89.

19 The report of commodore Wainwright, commander of the squadron, describing the capturing of the fort on the island of Qeshm, in: J. Marshall, Royal naval biography, London 1829, vol III, 89-90.

20 Most likely sloops, for most of the HEIC's armed vessels belonged to this class.

21 Java, a part of the Dutch East Indies, during the Napoleonic Wars became a titular colony of the Empire. In the late summer of 1811 it was captured by British forces, supported by the fleet and units of the British East India Company. The gathered naval forces: four third rate ships, fourteen fifth rates and fourteen cruisers: brigs and sloops on the Royal Navy's part, and also eight ships of the HEIC were pretty much the whole British sea power on
} 
sea-lanes of the Indian Ocean remained unguarded ${ }^{22} .1812$ saw the renewal of active, not to say brazen, actions of the Al Qasimi. In 1813 a number of large freighters fall into their hands - some of them under the British flag, traversing the shipping lanes from Basra $^{23}$ and Kangun ${ }^{24}$. Many others remain in port, fearing for their fate ${ }^{25}$. In 1813, as the losses in trade in the whole Persian Gulf began to increase, it became obvious that the "loyal" sheikh of the Al Qawasem, Sultan bin Saqr, either was not able to meet his obligations, or simply had no interest in it. In the face of such a situation Sayyid Said, Sultan of Muscat and Oman, turned to the Company's authorities in Bombay, with a willingness to take action with them in order to overcome the threat ${ }^{26}$.The Company's agent in Bushehr, Lieutenant Bruce, accompanied this expedition to be the witness to the pacification of the common enemy (or open negotiations with them, if the need occcured $)^{27}$. Yet it came to nothing. The next expedition, in 1814, proved to be slightly more successful. The Al Qawasem committed to refrain from aggression against the inhabitants of both shores of the Gulf of Oman and the regions in the Persian Gulf between Bahrain and Kangun. These were supposed to be the territories of Muscat and, as such, they were to be protected from the piracy. All stolen goods were to be returned ${ }^{28}$. Naturally, none of the points of this agreement was realized. An interesting issue for a historian or a political scientist to research would be the question to what degree the parties believed in the realization of these resolutions.

It was just another in a series of similar agreements made in over the previous years, with all previous ones broken. Granted, it is hard to determine due to the lack of sources or limited access to thereof, yet it seems probable that the effects guaranteed by such a treaty were, let us say, short-term. In the case of the Sultan's actions it was an opportunity to finish the expedition and announce its success to avoid for a second time returning as a defeated party. In the meantime, during the absence of Sayyid and his armies in Ras al-Khaimah or shortly after their evacuation, the Al Qawasem captured a Persian merchant ship plying its trade between Muscat and Bandar Abbas - a Persian harbour under the rule of Oman ${ }^{29}$. It was reclaimed after a vicious fight and serious casualties on both sides. No restitution of goods ever took place, even though the ink had barely dried on the treaty ${ }^{30}$.

the waters of the Indian Ocean. W. James, The naval history of Great Britain, London 1827, vol. 5, 295-310. The detailed list of the units of the fleet on the page 303.

22 R. Woodman, The Victory of Seapower, 1806 - 1814, London 2003, 91.

23 Trade documents of the Company concerning the trade in Basra. British Library, Asian and African Studies, IOR/F/4/366/9190; most of the others can be found in the same collection, under the catalogue number: IOR/G/29.

24 Kangun as a trading port was important enough for its governor to receive quite expensive presents from the British residents. British Library, Asian and African Studies, IOR/F/4/307/7041

25 Ibid. The Company's letters.

26 J.G. Lorimer, Gazetteer of Persian Gulf, Oman and Central Arabia, Kolkata 1915, 650. It is a particularly vast description of these regions commissioned by the Indian Office. It is available as a whole at the Qatar Digital Library, under the catalogue number IOR/L/PS/20/C91/1-2

27 British Library, Asian and African Studies, IOR Neg 11689 - Diary of Capt William Bruce, Resident at Bushire 1808-22, including copies of official correspondence.

28 Lorimer, 651.

29 Ibid.

30 Considering the dates of both incidents, it is possible that during that attack the ink was actually still drying, which would have added even more irony to the whole situation. 
The Sultan only option was once again to ask the Company's help in solving the piracy problem. However, both the Company's authorities and Lieutenant Bruce as its representative rejected any attempts to interpret the Omani-British Treaty as a military alliance. Meanwhile, they kept trying to obtain the compensation for their losses from the authorities of Ras al-Khaimah and, if possible, negotiate a treaty with local tribes. Hence, Bruce's participation in all Omani expeditions. This was interpreted by the Sultan as a sign of support. Yet he did not achieve intended goals because he was not invited to the negotiating table $\mathrm{e}^{31}$. The Sultan had mostly his own interests in mind, namely maintaining the control over Ras al-Khaimah. The plan's objectives were takeover of this Emirate in exchange for maintaining the authority of the sheikh of Al Qawasem in the Emirate of Sharjah, and some additional privileges ${ }^{32}$. Approximately three months later, the Sheikh of Shiraz made an agreement about cooperation with the Shah of Persia in the matter of control over Bahrain ${ }^{33}$.

Perhaps it is worth explaining why Bahrain at that particular moment in history had become the trouble spot of the Gulf. In the author's opinion it proved crucial for long-term inability to provide commercial and political stability in the region, because of its location and the unclear status. The island was controlled by the Portuguese since the end of the 15th century till 1602, when the peasants' revolt removed them from the Bahrain Fort ${ }^{34}$. Next the island fell under control of the Safavid who kept it in their sphere of influence thanks to the combination of political manipulations and precisely dosed ideology. It was a period of economic and cultural growth. Pearl fishing, steady trade and development of theological schools were reinforcing the Persians and their power over that territory ${ }^{35}$. Although, when at the beginning of the $18^{\text {th }}$ century the Afghan invasion threatened to cause the fall of the Safavid ${ }^{36}$, the control over the lonesome outpost of the Fort was broken. The Oman forces and the confederation of Al Bin Ali tribes conquered the island and, having looted $\mathrm{it}^{37}$, resold it to the Persians. It did not prevent the Omanis from collecting high taxes and duties, while Persia was too weak to provide peace to the island. The opportunity to come to power was taken by the Huwala tribe. In 1730 the Persian fleet took over the island once more, which had been perceived as a challenge for - strong at that time - Omanis. The latter, not wanting to weaken the position they had managed to achieve, asked the British and the Dutchmen for help, and in 1736 they made Bahrain submit to them once more. Persia, too weak to respond, was forced to withdraw. However in 1753 the Arabian tribe of Abu Shahr launched an attack, seized the island for itself and, having paid a tribute to the shah, proclaimed itself a vassal of Persia. As can be seen, this small yet affluent island was the axis of the conflict between two local powers. In 1782 a war broke out between Bahrain, remaining under the control of Persia, and the emirate of Zubarah ${ }^{38}$, located in the territory

31 British Library, Asian and African Studies, IOR Neg 11689

32 Lorimer, 651.

33 Ibid.

34 C. Larsen, Life and Land Use on the Bahrain Island, Chicago 1983, 68-69.

35 J. Cole, Sacred Space and Holy War, Detroit 2007, 50.

36 M. Axworthy, History of Iran, New York 2010, 39-55.

37 During the invasion and in the following years three hundred from three hundred and sixty cities, settlements and villages on the territory of Bahrain would be destroyed. J. Cole, Sacred Space and Holy War, Detroit $2007,52$.

38 Zubarah was located on the territory of present-day Qatar and was an important trade center in the region, playing also a strategical role, as situated in the middle of the Strait of Hormuz. In the $20^{\text {th }}$ century it was abandoned. 
of today's Qatar, at that time in the sphere of Muscat's influence ${ }^{39}$. The Bahrainis, having called their kinsmen from the Persian shore for help, launched an attack on Zubarah fort, though they were repulsed due to the arrival of the coalition of the Bani Utbah tribe's emirates, the rulers of, i.a., Kuwait. After repelling the attack, in revenge, in 1783 the forces of the coalition attacked the Bahrain Fort and captured it. This is where the controversy arises, because historians have different opinions about the sequence of events and the question of who attacked first. Another, quite reasonable theory suggests that the forces from Kuwait never made it to Zubarah, but, having learned about the Persians' retreat, attacked nearby Bahrain $^{40}$.Regardless of the version, Ahmed ibn Chalifa gained the absolute power over both emirates and ruled them till his death in 1796. Further Persian invasions were impossible due to the internal weakness of Persia, yet, unexpectedly, this time it was the Omanis who turned against their recent allies and vassals, attacking them in 1799 and 1800. By taking over Muharraq Island at the coast of Bahrain and establishing there a garrison with the son of sultan Sayyid as the leader, they intended to provide themselves a stable position at the gates of the emirate. And here we slowly return to the events this article deals with. In 1801 the garrison was removed; in 1802 the Omanis made another attempt of attack and were defeated. The ships and soldiers of the emir of Al Qawasem engaged in the fight for Bahrain in 1814, on the side of the Persians, who for a long time had not displayed such tendencies. This decision, considering their strength and previous efficiency, could have had a significant impact on geopolitical situation of the Gulf. It was not the only peculiar move on their part. Hasan bin Rahman, their ruler, reassuring that he respected British units' neutrality, send an envoy and letters to Bombay ${ }^{41}$. He tried to present himself as forced to wage a constant naval warfare for dominance, and all victims of piracy were merely its side effect. He even offered a restitution of goods and these ships that would be proven to have been stolen by pirates $^{42}$. Even the possibility to conclude a treaty with Great Britain; what is interesting, his terms in the most part corresponded with those proposed by the British in 1820. The ships of Al Qawasem were to receive a special flag to distinguish them from non-treaty ones, the possessions of the Company, along with the ship „Ahmad Shah ${ }^{43}$ "were to be given back, and all harm done to each other forgotten. Authorities in India approved on this proposition and in August of the same year even sent the letters, asking for the execution of the treaty's terms in the matter of the pirates who had seized a couple of boats under the British flag ${ }^{44}$.

Al Qawasem though, supported by the first Saudi State - who also pressured them due to their dislike for the "infidels" - became impudent. They attacked not only British vessels, but also American or French ones; they even took over the ship transporting the supplies

H. Rahman, The Emergence of Qatar: the turbulent years 1627-1916, London 2005, 35.

39 Lorimer, vol. 1, 1000.

40 British Library, Asian and African Studies, MssEur F206/55

41 British Library, Asian and African Studies, MssEur F206/55

42 Lorimer, 652.

43 This vessel, sailing under the Company's flag, was captured by the sheikh of Cbarak, who, inspired by the success of Ras al-Khaimah pirates, decided to participate in their criminal activity. The ship was seized in Qais, and then its captors were robbed by their ,teachers". It is worth noting that bin Rahman decided to make a pact not before consulting the Saudi. MssEur F206/55

44 British Library, India Office Records and Private Papers, IOR/L/PS/20/C248C, part II. 
for the 17th Light Dragoons, at that time serving in India ${ }^{45}$. Seeing the profitability of their actions, numerous ships and groups in the region followed their example. As a result, the British resident could not even safely send a letter of protest concerning that matter ${ }^{46}$.

Soon a new wave of incidents reached the Red Sea as well, forcing the British - once more - to intervene more actively. The Company sent four ships to Ras al-Khaimah, demanding a compensation and returning the goods stolen during their plundering expeditions to that distant water area. They also wanted either the emir to resign or two of his sons to stay in Bombay as hostages ${ }^{47}$. They were ignored though, in a quite arrogant way. Unfortunately, weather conditions forced them to leave; they came back after thirty days ${ }^{48}$.

The ships bombarded four Arabian units anchored in the roadstead, their destruction intended to be a warning ${ }^{49}$. Subsequently one part of the squadron, given similar mission, set off to other ports, and the other returned to the escort of the convoys. At that time the tribe had sixty ships of appreciable size, able to carry from eighty to three hundred people, and fourty smaller units ${ }^{50}$. Assaults continued, in the October of 1817 striking even large settlements and villages not far from Bushehr ${ }^{51}$. Cruisers of the Company strove to repel these attacks but quite often found themselves trapped as well ${ }^{52}$. Some actions of a greater range seemed unavoidable.

Finally, fed up with constant trouble in this area and at last possessing enough resources to -hopefully - solve the problem once and for all, in 1819 the Great Britain launched the third anti-pirate operation in the Persian Gulf. After the end of Napoleonic Wars, conflicts with the Gurkhas, a conflict with the Pindaris and wars with the Marathi ${ }^{53}$, it was finally possible to gather sufficient forces. Depending on the analysis, three to five thousands of soldiers were expected to be needed, along with adequate naval forces ${ }^{54}$. At the same time the Egyptian army of Muhammad Ali took over the central regions of the Arabian Peninsula, so the authorities of the Company decided to wait, in hope that this power would solve the problem for them. It did not; moreover, in the matter of the Egyptians staying in the region of

45 MssEur F206/55

46 British Library, India Office Records and Private Papers, IOR/L/PS/20/C248C, part III

47 Ibid.

48 Lorimer, 55.

49 MssEur F206/55

50 Lorimer, 55.

51 Among them was, for example, Shaikh Shu'aib, where all villages on the western end of the Island were destroyed, Asalu, where on the road stead pirates captured five merchant ships with cargo worthy of eight hundred thousand rials (a hundred thousand pound sterlings at the time!) or Daiyir. British Library, Asian and African Studies, IOR/R/15/1/19, collection of documents of the Political Resident at Bushire - inward letters from January 1817 to December 1819.

52 Lorimer, 53-54 - For example in January 1816 the Company's cruiser Aurora was attacked. The fourteen-gun schooner was attacked by fifteen large pirate units, and shortly after the cruiser Turrarow was attacked as well. In letters of Political Residents and the correspondence of the Bombay Presidency a lot of similar incidents can be traced.

53 British Library, Asian and African Studies, MssEur F175/23. It was the last war with Marathi, which to a large extent determined the situation and degree of British domination in India. As a result, the British finally conquered the area matching approximately the territory of present-day India. The subject is also largely described in quite old work by J. Duff, History of Mahrattas, London, 1921.

54 Lorimer, 658. 
the gulf, the governor of Bombay displayed a particularly bad attitude, to say the least ${ }^{55}$. This time, before beginning the expedition, the consequences and possible further actions were taken into consideration. Granting the rule over these territories to Sayyid of Oman would have partially solved the problem and allowed undisturbed development of British colonization on the island of Queshm, located in a strategic place at the mouth of the Persian Gulf ${ }^{56}$.

The plan included acknowledgement of hereditary rule of the sultan of Oman on the territories of the Pirate Coast and Bahrain - the sheikh of which, according to the governor, had lost his right for lying claim to any power by hiding and protecting the pirates. The shah of Persia, in exchange for renouncing the rights to Bahrain, was to receive annually thirty thousand tumans ${ }^{57}$ from around two hundred thousand which was the income of the island at that time. The plan had its weaknesses... first of all, the doubts, not as much moral as legal and political, about depriving Bahrain of independence ${ }^{58}$. Not less doubtful was the shah's and his government's acceptance of this agreement, for Queshm was too important for them to easily agree for $\mathrm{it}^{59}$. The other considered option was supporting the sultan militarily and financially in dominating the troublesome emirates and the island itself.

Either way, it required obtaining the consent of both sultan and Ibrahim Pasha, the Egyptian general controlling the neighbouring Arabian territories. In order to know what their stances were and initiate the negotiations, in April 1819 an envoy was sent to them, captain George Forster Sadleir ${ }^{60}$, with the proper letters. First he travelled to the sultan of Oman. Since his role in the plan was a crucial one, it was important to know his stance first, learn whether he was ready to engage in the plan or not and how much he was willing to invest in its realization. Only after this the negotiations with Ibrahim would become possible. The captain's arrival to Muscat exposed already in the beginning the elementary problems with the whole idea - the sultan was not willing to cooperate with the Egyptians, whose presence in Arabia he perceived as a threat ${ }^{61}$. Although he promised to estimate the strength of $\mathrm{Al}$ Qawasem, and provide the military support and supplies, he did not agree for any pact with Ibrahim. Sandleir, who managed to become the first European to cross the Eastern Desert in the summer, had a hard time finding the Egyptian leader ${ }^{62}$. The Egyptian forces were in

55 British Library, Asian and African Studies, IOR/R/15/1/20, collection of documents of the Political Resident at Bushire - outward letters from January 1817 to December 1819.

56 Lorimer, 659.

57 Tumanis a name of Persian monetary unit, in that period worthy of approximately eight riala or one British pound. At the same time this word was commonly used as a name for the most of the silver coins in the region.

58 Lorimer, 660.

59 British Library, Asian and African Studies, IOR/R/15/1/20, collection of documents of the Political Resident at Bushire - outward letters from January 1817 to December 1819.

60 George Forster Sadleir - captain of the 47th Foot Regiment - a part of the Bombay Presidency's army -on political staff of Sir John Malcolm and, as mentioned in the text, a special envoy of the Company to Ibrahim Pasha. Known as a first European (at least documented) to cross the desert of Arabian interior in the summer. Despite the failure of his mission, he gathered incredibly valuable geographic information that expanded the knowledge about this mostly unfamiliar to the Europeans region. His memoir was published in 1866 at the order of the Governor of Bombay, under the title of: Diary of a Journey cross Arabia from El Khalif In the Persian Gulf, to Yambo In the Red Sea, during the Year 1819. It is available for free, for example on "google book" sand is a fascinating source of information about this journey. An equally interesting source are the papers of his regiment, in: Lancashire Infantry Museum,47th \& 81st Food. 846/2.4.137-8

61 Lorimer, 662.

62 See: A diary mentioned in the footnote 59. 
the process of withdrawing from the interior and only after a long search in the increasing chaos, the messenger managed to meet him on the $8^{\text {th }}$ of September. He handed him the letters from the Governor-General and the Governor of Bombay, and a gift - a ceremonial sword. Then he waited for an answer. Despite the optimistic assumptions, Ibrahim Pasha was unable to independently make a decision, and Muhammad Ali had not yet sent any answers from $\mathrm{Kair}^{63}$. There was nothing left but to assume the Egyptians are not interested and come back. Granted, there were chances of another military expedition being successful - Al Qawasem were deprived of the help of the recently destroyed Saudi, who had previously been reinforcing the power of bin Rashid. But there was a lack of good long-term solutions, especially in case of the protest on the part of, this time, Persian government, afraid of British intervention in its region of jurisdiction - for not only the sheikdoms of the southern coast of the Gulf were enriching themselves on piracy ${ }^{64}$. It resulted in need for sending more letters and explanations ${ }^{65}$.

Meanwhile the preparations to the next military mission continued. It was to consist of three vessels of the Royal Navy ${ }^{66}$ and six cruisers of the Company ${ }^{67}$.The land forces were to be: 47th Regiment ${ }^{68}$, 65th Regiment, a battalion from the 2nd Regiment of Native Infantry, a company from the $3^{\text {rd }}$ Regiment Native Infantry, half of the company of pioneers, a battalion of Marines and a company of artillery ${ }^{69}$. Three thousands of soldiers in total. The instructions from the leader of the expedition, general William Keir Grant ${ }^{70}$,were simple. The main goal was destroying the pirates of Ras al-Khaimah, though the general did not intend to occupy the land territories for a long time, let alone encroaching on Persian government's authority. Besides, political and military actions were meant to prevent the rebirth of piracy or strong Wahhabi centres on the Coast ${ }^{71}$.

The mission began in due time and despite some skirmishes with enemy ships during the cruise, as early as the $25^{\text {th }}$ of November Liverpool and Benares arrived to the port in Ras al-Khaimah and blocked it, while the rest of the ships collected water and supplies on the island of Queshm. On the $2^{\text {nd }}$ of December full British forces appeared, and together with them four troopships with army and two frigates from Muscat as the sultan's support for expeditionary forces ${ }^{72}$.

\footnotetext{
63 Lorimer, 662.

64 British Library, Asian and African Studies, IOR/R/15/1/19-20, collection of documents of the Political Resident at Bushire - inward and outward letters from January 1817 to December 1819.

65 Correspondence of sir Robert Campbell, the director of the East India Company, with sir Henry Willock, a chargé d'affairesin Teheran, sir John Malcolm, a ruler of Central India, and other officials of the Company. British Library, Asian and African Studies, MssEur D556/3.

66 HMS Liverpool (50 guns), HMS Eden (26 guns) oraz HMS Curlew (12 guns). Lorrimer, 664.

${ }_{67}$ Teignmounth, Benares, Aurora, Nautilus, Ariel and Vestal - first two sixteen-gun, another two fourteen-gun and last two ten-gun. Ibid.

68 Lancashire Infantry Museum,47th \& 81st Food. 846/4.2.

69 Lorimer, 665.

70 Originally William Keir or William Grant-Keir, baron „of Austria of Blackburn”. General of the Napoleonic Wars, son of Archibald Keir, an official of the Company. The Dictionary of National Biography, vol. 22, http:// onlinebooks.library.upenn.edu/webbin/metabook? $\mathrm{id}=\mathrm{dnb}$, access to digital content 03.03.2015.

71 Lorimer, 664.

72 Ibid.
} 
Since the year of 1809 , when the British had stormed this city for the last time, a lot of things had changed. A new wall had been built and the fort had been renovated ${ }^{73}$. On the $6^{\text {th }}$ of December an artillery shoot-out began, though the invaders had a significant advantage. The defenders seemed to not have a sufficient reserve of ammunition, because according to accounts, they used pieces of rock as missiles, and at night tried to collect British cannonballs. After three days of bombardment, on the $9^{\text {th }}$ of December, British columns entered the empty fort at night, capturing eighty ships anchored in the port $\mathrm{t}^{74}$ and about seventy cannons - mostly completely broken or incredibly old. Casualties amounted to fifty seven people, while the enemy, depending on the source, lost from four hundred to one thousand people - it is extremely hard to determine though ${ }^{75}$. Therefore, the victory was not a breakthrough; moreover, the supplies were clearly insufficient - which, by the way, resulted in sending away the land expedition of Omani forces that appeared two days too late. The Company's cruisers were sent to the rest of the local ports in order to block them until main force arrives ${ }^{76}$. In the meantime the British attacked Dhayali, where Al Qasimi fugitives had hidden. Their improvised fortifications had been besieged by a battalion of infantry and eight cannons. The defenders did not decide to surrender and resisted for four days before, after long and persistent bombardment, capitulated in exchange for a guarantee that their life would be spared ${ }^{77}$. Many of the remaining ports had been abandoned and a significant number of vessels could not be found. The old fort in the main base of the pirates was blown up, and then new fortifications were garrisoned with eight hundred of sepoys. Yet further search for the enemy was rather ineffective. It was the time for negotiations.

Those were not an easy task. Local sheiks could be categorised into a few groups. First, naturally, was that in which the British were interested the most - the captured sheikhs-pirates. Then there were pirate rulers who remained free, yet were willing to negotiate, sheikhs like the one from Bahrain, making money on piracy, and those who were not involved in anything, and even protected by Oman or Persia. General Grant decided that all the sheikhs had to sign initiatory contracts, each one of them a different one, adequate to the specific circumstances that concerned $\mathrm{him}^{78}$. Only fulfilling them would allow signing the treaty the general was going to offer them. Apart from the stick, Grant decided to also use a carrot. He returned the fishing and pearl-fishing boats. Hasan bin Rahman lost Ras al-Khaimah, yet he kept the emirates Hatt and Fahleia ${ }^{79}$.

Finally, in 1820, there was signed a treaty that guaranteed giving up piracy and robbery on both land and water by its signatories. It also precisely distinguished legal military operations from simple acts of plunder, and ordered to mark the ships of sheikdoms-signatories

\footnotetext{
73 British Library, Asian and African Studies, IOR/R/15/1/23, a report to Bombay and Bushehr decsribing the expedition to Ras al Khaimah, Qeshmand Muscat, as well as the translation of the correspondence with the sultan of Muscat.

74 From little to quite large ones. Lorimer, 667.

75 Ibid.

76 British Library, Asian and African Studies, IOR/R/15/1/23

77 Ibid.

78 The common points were giving up the equipment used in pirate actions and releasing the Indian captives. The recordings of initiatory contracts can be found in: Reports from Committes, 1831-32, East India Company 's Affairs, tom 10, appendixes, 499 and further.

79 Lorimer, 671
} 
with a special flag. It forced the necessity of registration of all watercraft at British offices and creating port books in which sea lanes and cruises of the ships that anchored there were to be recorded. The task of taking care of it was entrusted to a new British resident who had the power to intervene in order to maintain the treaty. The same duty was given to the signatories - if a need arose, they were to participate in punishing those who broke the conditions. Killing captives and slave trade was condemned. On their part the British guaranteed they would not lay any territorial claims, gave a rather vague guarantee of safety and granted the merchant ships from emirates the right to use their ports without payment ${ }^{80}$.

Although the government in Bombay praised the efficiency, quickness and humanitarianism of Grant's actions, he doubted in some of the conditions he had offered to the defeated. Freeing the sheikhs responsible for the attacks seemed inappropriately itself, let alone leaving them the fortifications or part of their weaponry. Moreover, the allied Muscat did not gain anything. And the idea of registering watercraft guaranteed merely an illusion of safety ${ }^{81}$. The general though defended himself fiercely, emphasizing his efforts to not force the Company's government to involve in the region, which would be necessary in case of taking away from the emirates any possibility to defend themselves - after all some of them, like Bahrain, were important centres of the trade, for the British too. Besides - it would have been unwise to create the conditions impossible to enforce ${ }^{82}$.

The agreement did not change that much. Until the sheikhs did not agree in 1835 to give up naval warfare and did not sign the convention banning the fights during pearl fishing season and ten years of armistice, the fights continued. The growth of trade and riches guaranteed by this treaty eventually ended the conflicts. It led to signing in 1853 the Treaty of Maritime Peace in Perpetuity, and in 1892 the treaties about the protectorate.

However the British military actions against pirates were effective, they required constant naval presence in the region, which neither Royal Navy nor the Company's fleet could not provide in sufficient degree. The oceans of the world were simply too vast, and political means insufficient. What could not have been changed by cannons and muskets, was changed by the economic boom that made the countries of this regions find themselves in the sphere of influence of Great Britain or among its friends up to this day.

\section{The East India Company and the pirates of the Persian Gulf from the first punitive expedition to the signing of the General Maritime Treaty Summary}

Although almost every sea was dominated by Royal Navy, it couldn’t reach every single place in the world. Trade company's ships and fully armed merchant ships many times had to take care of themselves. The East India Company had an independent policy that goes beyond the subcontinent. During the first decade of 19th century, the most difficult problem to solve (except the problems of India) was the Persian Gulf, which appeared to be the source of many profits and problems, that wasn't easy to solve and took a lots of time to conclude.

\footnotetext{
${ }^{80}$ General Treaty with the Arab Tribes of the Persian Gulf, concluded by Major-Gen. Grant Keir 8th Jan. 1820 - in: British Library, Asian and African Studies, Miscellaneous treaties and grants, IOR/H/641, no. 406A-D.

81 Lorimer, 672

82 General Keir received as a gift from the Governor of Bengal, ten thousand rupees for the service of Sawantvadi and the mission in the Persian Gulf. British Library, Asian and African Studies, IOR/F/4/801/21443
} 
The Treaty of 1820 solved the problems of sea and overland campaigns. The times before signing the agreement and the way, it was created are included in this article.

Keywords: East India company, Pirate Coast, Persian Gulf, XIX century, maritime operations

\section{East India Company a piraci Zatoki Perskiej od pierwszej ekspedycji karnej do zawarcia General Maritime Treaty}

\section{Abstrakt}

Mimo iż Royal Navy dominowała nad prawie wszystkimi morzami świata, nawet ona nie mogła być obecna wszędzie. Okręty Kompanii handlowych, jak i uzbrojone statki kupieckie nie raz musiały samodzielnie dbać o swoje bezpieczeństwo, Kompania Wschodnioindyjska zaś nie raz prowadzić samodzielną politykę wykraczającą poza obszar subkontynentu. W ciągu pierwszych dekad dziewiętnastego wieku największym problemem poza Indiami okazała się Zatoka Perska - źródło licznych dochodów i jeszcze większych trosk, usunięcie których okazało się kosztowne i długie. Kłopotliwym kampaniom morskim i lądowym - a po prawdzie w znacznej mierze ekspedycjom karnym - kres położył dopiero traktat wymuszony w 1820 roku, zaś okres przed nim i sposób jego zawarcia opisuje niniejszy artykuł.

Słowa kluczowe: Kompania Wschodnioindyjska, Wybrzeże Piratów, Zatoka Perska, XIX wiek, operacje morskie

Nota o Autorze: Andrzej Pierzchała - doktorant historii w Instytucie Nauk Historycznych UKSW, zajmujący się tematyką polityki bliskowschodniej Wielkiej Brytanii jak i kwestiami związanymi z Imperialnymi. 